\title{
Prevalence of diarrheal illness and healthcare-seeking behavior by age-group and sex among the population of Gaza strip: a community-based cross-sectional study
}

\author{
Samer Abuzerr', Simin Nasseri ${ }^{2,3^{*}}$, Masud Yunesian ${ }^{2,4}$, Mahdi Hadi ${ }^{3}$, Amir Hossein Mahvi $^{2,3}$, Ramin Nabizadeh ${ }^{2}$ and \\ Ayman Abu Mustafa ${ }^{5}$
}

\begin{abstract}
Background: In the Gaza strip, diarrhea is one of main reasons for children visiting primary healthcare centers. Hence, we investigate predictors of the diarrheal illness and health care-seeking behavior among different age groups.

Methods: This community-based cross-sectional survey was conducted from August 2017 to June 2018 among 1857 households. A pretested structured questionnaire included information about socio-demographic, sanitation, hygiene, source of water, diarrheal illness, and seeking healthcare in households was administered to head of household. To achieve representativeness for the five Gaza's governorates, a cluster random sampling was applied.

Results: Of the 1857 household's heads, 421 (22.7\%) reported an episode of diarrhea during the $48 \mathrm{~h}$ preceding the interview resulting an overall prevalence rate of 3.8 per 100 individuals. The prevalence of diarrhea was statistical significant greater in males (5.4/100) compared to females (1.3/100) in all age groups $(p<0.05)$. Socio-demographic, economic, water, sanitation, and hygiene factors were predictors of the diarrheal illness and seeking of non-professional healthcare for diarrhea illness treatment among. A transition behavior from professional to non-professional and vice versa in seeking healthcare in each diarrheal episode was found.
\end{abstract}

Conclusions: We recommend improving the status of water, sanitation, and hygiene in the Gaza strip's households to reduce diarrhea among the population of Gaza strip. Community sensitization about the importance of seeking care at primary health centers because treatment of children is available for free or in low costs.

Keywords: Behavior, Diarrheal illness, Gaza strip, Healthcare seeking, Water source

\section{Background}

Diarrhea is the second worldwide most common cause of death in children below the 5 syears old in particular. According to the world health organization (WHO), more than 760,000 children a year die as a consequence of

\footnotetext{
* Correspondence: naserise@tums.ac.ir

${ }^{2}$ Department of Environmental Health Engineering, School of Public Health,

Tehran University of Medical Sciences, Tehran, Iran

${ }^{3}$ Center for Water Quality Research (CWQR), Institute for Environmental

Research (IER), Tehran University of Medical Sciences, Tehran, Iran

Full list of author information is available at the end of the article
}

diarrheal diseases [1]. Young children especially who are living in low-income states are at great risk for diarrheal consequences such as dehydration and malnutrition. Country-based investigations are highly relevant to identify diarrheal illness related-risk factors and inspect of healthcare-seeking behavior in society and recognize its implications on public health [2].

In the Gaza strip, diarrheal illness is the main cause for childhood visits to primary healthcare centers and hospitals [3]. Moreover, the United Nations relief and works agency for Palestine refugees in the Near East (UNRWA)

(c) The Author(s). 2019 Open Access This article is distributed under the terms of the Creative Commons Attribution 4.0 International License (http://creativecommons.org/licenses/by/4.0/), which permits unrestricted use, distribution, and 
revealed that the prevalence of diarrhea was 4017.1 case per 100,000 inhabitants in 2009 , thereafter rose to 6448.2 cases per 100,000 inhabitants in 2013, resulted mainly from alter of water quality, sanitation facilities and hygiene practices (WASH) at households [4].

Factors influencing healthcare seeking behavior, include individual factors, accessibility to service, the severity of illness, the trust of healthcare providers, and prior beliefs concerning treatment of the illness [5-7]. Moreover, the presence of considerable social, economic and information constraints would limit the use of publicly-funded healthcare and seek professional healthcare [8].

Traditional practices at houses revealed improper treatment of diarrhea in which delay seeking health care has resulted in a remarkable number of mortalities [9, 10]. Therefore, understanding the constraints are crucial especially in poverty-stricken communities like in Gaza strip to mitigate the barriers and evaluate the effectiveness of such interventions [11].

The Palestinian National Authority is the main health insurance provider and allocates $37.7 \%$ of its annual budget to the health sector. The Palestinian ministry of health is responsible for providing health services to the Gazans. The majority of $\mathrm{MOH}$ funding comes from foreign aid and fees for health services [12]. The Ministry of Health has about 54 primary healthcare centers (PHCCs) and 13 hospitals distributed throughout Gaza strip governorates. Furthermore, the nongovernmental organizations (NGOs) and the private health sector play a vital role in the provision of third-care services, outpatient clinics, and rehabilitation centers through 8 PHCCs and 14 hospitals [13]. The UNRWA has 22 health centers which offer primary healthcare to Palestinian 1,167,572 refugees in the Gaza strip [12]. The surveillance system for communicable diseases in the Gaza strip remains limited due to lack of logistical capacity and financial resources.

Understanding risk factors associated with the occurrence of diarrhea in all age groups of the society and the predictors of seeking non-professional healthcare for diarrhea treatment may be helpful in reducing diarrheal morbidity and mortality. To the best of our knowledge, burdens of diarrheal diseases and health care-seeking behavior among the population at risk in Gaza strip have not been assessed. Thus, the aim of this study was to identify diarrheal illness related-risk factors and predictors for seeking nonprofessional care for diarrhea treatment among the population of Gaza strip. Moreover, the trend of seeking healthcare behavior from professional and non-professional healthcare providers in the last three diarrheal episodes was explored.

\section{Methods}

\section{Study design and setting}

This community-based cross-sectional study was carried out from 1st of August 2017 to 28th June 2018 in the
Gaza strip. Gaza strip classified as the third most densely populated areas in the world and includes five governorates as follow: North Gaza, Gaza, Middle area, Khan Younis, and Rafah governorate [14].

\section{Sample size calculation}

The sample size in this study was calculated using the following formula [15]:

$$
\begin{aligned}
\text { Sample size }(n) & =\frac{Z_{1-\alpha / 2}^{2} P(1-P)}{d^{2}} \\
& =\frac{(1.96)^{2}(0.50)(1-0.50)}{(0.05)^{2}}=384
\end{aligned}
$$

Where, $Z_{1-\alpha / 2}=$ Standard normal variate $(Z$ value is 1.96 for a $95 \%$ confidence level). $\mathrm{p}=$ Response distribution (50\%). $d=$ Margin of error (5\%).

The calculated sample size was 384 households. Unexpectedly, after data collection had finished, some items have gotten zero frequency at the sample size of 384 households. Consequently, we have recalculated the sample size after decrease margin of error $(2.274 \%)$ to increase the sample size and raise the level of representation as well as to get a narrower confidence interval [16]. Eventually, the sample size calculated by the same equation with an adjusted margin of error was 1857 households.

$$
\begin{aligned}
\text { Sample size }(n) & =\frac{Z_{1-\alpha / 2}^{2} P(1-P)}{d^{2}} \\
& =\frac{(1.96)^{2}(0.50)(1-0.50)}{(0.02274)^{2}} \\
& =1,857
\end{aligned}
$$

\section{Data collection and sampling}

A cluster random sampling was applied to achieve representativeness from all Gaza's governorates. The number of surveyed households in each governorate was determined based on the total number of households in each governorate which was as follows: 126 in North Gaza, 466 in Gaza, 472 in Middle area, 477 in Khan Younis, and 316 in Rafah governorate. Data were collected by four well-trained interviewers and $15 \mathrm{~min}$ were enough to complete the questionnaire by face to face interview.

\section{Study tool}

A pretested structured questionnaire was administered to head of household and encompassed six parts [11]: socio-demographic (age, gender, housing area, monthly income, marital status, education level, etc.), sanitation status ( 4 items), hygiene status ( 1 item), sources of household water (3 items), diarrheal illness (4 items), and seeking healthcare (1 items), the participants were 
questioned about the professionalism of healthcare providers sought in the three preceding diarrheal episodes, as the selection of healthcare kind in each diarrheal episode might change. For categorical variables, the responses were measured on 2-point (yes/no) scale.

\section{Variable definitions}

In our study, acute diarrhea was defined according to the World Health Organization (WHO), as the passage of three or more abnormally loose, watery, or liquid stools over a 24-h period [17]. Professional healthcare provider denotes medical personnel in primary healthcare centers, hospitals, or pharmacies, whereas nonprofessional provider indicates non-medical personnel such as traditional medicine therapist and in-home therapist. Primary education is considered low education. Improved water refers to treated water. Less than 1500 Israeli new shekel (INS), the local currency, is classified as low monthly income ( 1 USD $\approx 3.6$ INS). Urban area is defined as a region with high population density and infrastructure of built environment, whereas rural area is defined as a region with low population density and small settlements. Agricultural areas are rural in nature.

\section{Statistical analysis}

The Statistical Package for Social Science (SPSS) version 20 was used for data analysis. Descriptive statistics of frequency and percentage, and mean and standard deviation were performed for categorical and continuous variables respectively. The independent samples t-test was applied to investigate the differences between means. The chi-square test was used to determine the statistically significant differences between the different categorical variables. The difference in individual and household level characteristics between those who 'reported diarrhea' and those who presumably did not have diarrhea was examined using the Chi-square test. The odds ratio (OR) and the confidence interval (CI) for the risk factors associated with diarrheal illness and for seeking nonprofessional care for diarrhea treatment were reported using logistic regression analysis. A $p$-value < 0.05 was considered statistically significant.

\section{Results}

\section{Socio-demographic characteristics}

Altogether 1857 head of households were surveyed. The mean age \pm SD of getting diarrhea was $15.6 \pm 16.5$ years old. About 611 (32.9\%) lived in rural areas, while 1246 (67.1\%) were from urban regions. Most of household's heads were highly educated 1607 (86.5\%). The vast majority of household's heads were males 1621 (87.3\%). Almost half of households lived with low income 908 (48.9\%). Only $610(32.8 \%)$ of households relied on non-improved water for drinking, whereas 1814 (0.98\%) and 1022 (55\%) used non-improved water for washing and cooking purposes, respectively (Table 1 ).

\section{Prevalence of diarrheal disease}

Four hundred twenty-one household head stated that there had been an episode of diarrhea within their household during the $48 \mathrm{~h}$ preceding the interview resulting in a prevalence rate of 3.8 per 100 individuals.

The prevalence rate of diarrhea among children $\leq 5$ years old was 11.7 per 100 individuals, while it was 1.2 and 3.1 in the age groups between 6 and 15 years old and more than 16 years, respectively. The overall prevalence rate for all age groups was 3.8 per 100 individuals. With regards to gender differences, findings revealed statistical differences between males and females and prevalence of diarrhea was higher in males in all age groups; $\leq 5$ years, $6-15$ years, $>16$ years $(15.8,2.1$, and 4.2 , respectively) $(P<0.001)$. By and large, diarrhea was more prevalent in males than females (5.4 and 1.3, respectively) $(p<0.001)$ (Table 2).

\section{Independent factors associated with diarrhea illness}

The logistic regression analysis showed that living in rural areas $(\mathrm{OR}=2.1 ; 95 \% \mathrm{CI}: 1.4-3.2)$, low education level of household's head ( $\mathrm{OR}=2.7 ; 95 \% \mathrm{CI}$ : 1.6-4.4), low monthly income $(\mathrm{OR}=2.4 ; 95 \% \mathrm{CI}: 1.7-3.5)$, having an unclean kitchen at home $(\mathrm{OR}=1.4 ; 95 \%$ CI: $1.1-1.8)$, having non-sanitary toilet at home $(\mathrm{OR}=278.6 ; 95 \% \mathrm{CI}$ : 99.9-777.4), using a latrine without flush $(\mathrm{OR}=2.5$; $95 \%$ CI: 1.1-5.8), disposal of wastewater in open area around house $(\mathrm{OR}=10.3$; 95\% CI: $6.9-15.5)$, and lack of soap for hands washing $(\mathrm{OR}=3.7$; 95\% CI: $2.5-5.4)$, were predictors for developing diarrheal illness (Table 3).

\section{Healthcare seeking behavior}

In bivariate analysis between those who sought healthcare from professional vs non-professional provider, we found significant differences and association with some independent variables. Education level, monthly income, and age of getting diarrhea are factors correlated with kind of healthcare seeking for treatment of diarrhea $(p<0.05)$ (Table 4).

To identify the trend of seeking healthcare behavior from professional and non-professional healthcare providers and vice versa. The 421 household's heads who indicated that there had been an episode of diarrhea within their household were asked about their seeking behavior concerning healthcare professionalism for diarrheal treatment in the last three diarrheal episodes. Approximately $52.6 \%(221 / 199)$ sought health care from a professional health care provider in the first episode of diarrhea, around 33.6\% (141/279) sought professional care provider in the second episode, whereas $66.4 \%$ sought non-professional healthcare. In last diarrheal 
Table 1 Comparison of individual and household level characteristics between those who reported diarrhea' and those who presumably did not have diarrhea

\begin{tabular}{|c|c|c|c|}
\hline Variables & $\begin{array}{l}\text { Did not get diarrhea } \\
n=1436(77 \%)\end{array}$ & $\begin{array}{l}\text { Got diarrhea } \\
n=421(23 \%)\end{array}$ & $p$-value \\
\hline \multicolumn{4}{|l|}{ Binary variables } \\
\hline \multicolumn{4}{|l|}{ Housing area } \\
\hline Rural & $390(27.2)$ & $221(52.5)$ & \multirow[t]{2}{*}{0.001} \\
\hline Urban & $1046(72.8)$ & $200(47.5)$ & \\
\hline \multicolumn{4}{|c|}{ Marital status of the household head } \\
\hline Married & $1192(83.0)$ & $344(81.7)$ & \multirow[t]{2}{*}{0.536} \\
\hline Single & $244(17.0)$ & $77(18.3)$ & \\
\hline \multicolumn{4}{|c|}{ Education level of household head } \\
\hline Less educated & $147(10.2)$ & $103(24.5)$ & \multirow[t]{2}{*}{0.001} \\
\hline High educated & $1289(89.8)$ & $318(75.5)$ & \\
\hline \multicolumn{4}{|c|}{ Gender of household head } \\
\hline Male & $1255(87.4)$ & $366(86.9)$ & \multirow[t]{2}{*}{0.803} \\
\hline Female & $181(12.6)$ & $55(13.1)$ & \\
\hline \multicolumn{4}{|l|}{ Career of household head } \\
\hline Craftsman & $510(35.5)$ & $162(38.5)$ & \multirow[t]{2}{*}{0.266} \\
\hline Public servant & $926(64.5)$ & $259(61.5)$ & \\
\hline \multicolumn{4}{|c|}{ Monthly income of household } \\
\hline Low income & $740(51.5)$ & $168(39.9)$ & \multirow[t]{2}{*}{0.001} \\
\hline High income & $696(48.5)$ & $253(60.1)$ & \\
\hline \multicolumn{4}{|l|}{ House ownership } \\
\hline Owned & $1323(92.1)$ & $399(94.8)$ & \multirow[t]{2}{*}{0.066} \\
\hline Rented & $113(7.9)$ & $22(5.2)$ & \\
\hline \multicolumn{4}{|c|}{ Gender of person who had diarrhea } \\
\hline Male & - & $257(61.0)$ & \multirow[t]{2}{*}{0.963} \\
\hline Female & - & $164(39.0)$ & \\
\hline \multicolumn{4}{|l|}{ Source of drinking water } \\
\hline Non improved & $462(32.2)$ & $148(35.2)$ & \multirow[t]{2}{*}{0.252} \\
\hline Improved & $974(67.8)$ & $273(64.8)$ & \\
\hline \multicolumn{4}{|l|}{ Source of washing water } \\
\hline Non improved & $1405(97.8)$ & $409(97.1)$ & \multirow[t]{2}{*}{0.407} \\
\hline Improved & $31(2.2)$ & $12(2.9)$ & \\
\hline \multicolumn{4}{|l|}{ Source of cooking water } \\
\hline Non improved & $758(52.8)$ & $237(56.3)$ & \multirow[t]{2}{*}{0.204} \\
\hline Improved & $678(47.2)$ & $184(43.7)$ & \\
\hline \multicolumn{4}{|l|}{ Clean kitchen } \\
\hline Yes & $1244(86.6)$ & $128(30.4)$ & \multirow[t]{2}{*}{0.001} \\
\hline No & $192(13.4)$ & $293(69.6)$ & \\
\hline Sanitary toilet & & & \\
\hline Yes & $1170(81.5)$ & $14(3.3)$ & 0.001 \\
\hline No & $266(18.5)$ & $407(96.7)$ & \\
\hline Kind of toilet & & & \\
\hline Latrine with flush & $960(66.9)$ & $31(7.4)$ & 0.001 \\
\hline Latrine without flush & $476(33.1)$ & $390(92.6)$ & \\
\hline
\end{tabular}


Table 1 Comparison of individual and household level characteristics between those who reported diarrhea' and those who presumably did not have diarrhea (Continued)

\begin{tabular}{|c|c|c|c|}
\hline Variables & $\begin{array}{l}\text { Did not get diarrhea } \\
n=1436(77 \%)\end{array}$ & $\begin{array}{l}\text { Got diarrhea } \\
n=421(23 \%)\end{array}$ & $p$-value \\
\hline \multicolumn{4}{|l|}{ Place of wastewater disposal } \\
\hline Open area around the house & $232(16.2)$ & $304(72.2)$ & \multirow[t]{2}{*}{0.001} \\
\hline Close sewerage system & $1204(83.8)$ & $117(27.8)$ & \\
\hline \multicolumn{4}{|l|}{ Availability of soap for hands washing } \\
\hline Yes & $1078(75.1)$ & 189 (44.9) & \multirow[t]{2}{*}{0.001} \\
\hline No & $358(24.9)$ & $232(55.1)$ & \\
\hline \multicolumn{4}{|l|}{ Continuous variables } \\
\hline Age of household head (years) & $41.3 \pm 13.3(22-67)$ & $41.5 \pm 14(22-67)$ & 0.801 \\
\hline Living in the area (years) & $15.9 \pm 10.5(1-44)$ & $15.5 \pm 10.5(1-44)$ & 0.432 \\
\hline Number of rooms in house & $2.7 \pm 0.9(1-5)$ & $2.7 \pm 0.8(1-5)$ & 0.612 \\
\hline Number of family Members & $6.2 \pm 1.7(2-12)$ & $6.2 \pm 1.7(2-12)$ & 0.529 \\
\hline Age of getting diarrhea & - & $15.6 \pm 16.5(1-67)$ & - \\
\hline Number of children less than 5 in family & $1.4 \pm 0.7(0-3)$ & $1.5 \pm 0.6(0-3)$ & 0.312 \\
\hline Distance to healthcare center (km) & $1.6 \pm 0.8(1-4)$ & $1.6 \pm 0.8(1-4)$ & 0.916 \\
\hline
\end{tabular}

For the continuous variables, the Mean $\pm \mathrm{SD}$ (min-max) were presented instead of frequency and percentage as in the binary variables

Chi-square test was used to examine the difference between the two groups

episode, the trend of seeking professional care providers quite improved and was in favor of professional providers $(44.5 \%)$ compared to $55.5 \%$ (187/233) who sought non-professional care (Table 5).

\section{Independent factors associated with seeking non- professional healthcare}

Six predictors were generalized for seeking nonprofessional healthcare for diarrhea treatment among the population of Gaza strip. These factors are a female head of the family $(\mathrm{OR}=2.1 ; 95 \% \mathrm{CI}: 1.1-4)$, low education level of household head $(\mathrm{OR}=4.9 ; 95 \%$ CI: $2.2-8)$, low monthly income $(\mathrm{OR}=4.1 ; 95 \% \mathrm{CI}$ : $2.7-7.5)$, age of getting diarrhea ( $>5$ years old) $(\mathrm{OR}=$ 2.2; 95\% CI: 1.1-4.4), living in rural areas $(\mathrm{OR}=9.1$; 95\% CI: 1.9-44.3), and disposal of wastewater in the an open area surrounding the house $(\mathrm{OR}=1.8 ; 95 \%$ CI: 1.1-3.1) (Table 6).

\section{Discussion}

In our study, we reported a high prevalence of diarrhea in the Gaza strip (3.8 per 100). Factors related to this prevalence are complex in nature including but not limited to ineffective sewage management and lack access to safe drinking water $[18,19]$. The epidemiological bulletin published by the UNRWA indicated a constantly increase in trend of diarrheal incidence between 2010 and 2013 [4]. Diarrhea is more prevalent among young children. The previous finding from the same population was consistent with ours. Kanoa and his colleagues found diarrhea highly prevalent among under 5 years old [20]. Similarly, the global pattern of diarrheal is alike and it is the second leading cause of mortality and morbidity in children less than five [21-23]. However, the burden of diarrhea remains heavy especially in industrialized countries where older ages represent a large portion of their populations [11]. A consensus between the results of our study and the final edition of the

Table 2 The prevalence of diarrhea by age and sex groups among the population of Gaza strip

\begin{tabular}{|c|c|c|c|c|c|c|c|c|c|c|}
\hline \multirow{2}{*}{$\begin{array}{l}\text { Age } \\
\text { group } \\
\text { (Years) }\end{array}$} & \multicolumn{3}{|l|}{ Male } & \multicolumn{3}{|l|}{ Female } & \multirow{2}{*}{$\begin{array}{l}P \text { - } \\
\text { value }\end{array}$} & \multicolumn{3}{|l|}{ Al sexes } \\
\hline & $\begin{array}{l}\text { No. of } \\
\text { individuals }\end{array}$ & $\begin{array}{l}\text { Diarrheal } \\
\text { cases }\end{array}$ & $\begin{array}{l}\text { Rate/ } \\
100\end{array}$ & $\begin{array}{l}\text { No. of } \\
\text { individuals }\end{array}$ & $\begin{array}{l}\text { Diarrheal } \\
\text { cases }\end{array}$ & $\begin{array}{l}\text { Rate/ } \\
100\end{array}$ & & $\begin{array}{l}\text { No. of } \\
\text { persons }\end{array}$ & $\begin{array}{l}\text { Diarrheal } \\
\text { cases }\end{array}$ & $\begin{array}{l}\text { Rate/ } \\
100\end{array}$ \\
\hline$\leq 5$ & 1075 & 170 & 15.8 & 687 & 37 & 5.4 & 0.001 & 1762 & 207 & 11.7 \\
\hline $6-\leq 15$ & 2064 & 43 & 2.1 & 1886 & 4 & 0.2 & 0.001 & 3950 & 47 & 1.2 \\
\hline$\leq 15$ & 3139 & 213 & 6.8 & 2573 & 41 & 1.6 & 0.001 & 5712 & 254 & 4.4 \\
\hline$>16$ & 3658 & 153 & 4.2 & 1772 & 14 & 0.8 & 0.001 & 5430 & 167 & 3.1 \\
\hline $\begin{array}{l}\text { All } \\
\text { ages }\end{array}$ & 6797 & 366 & 5.4 & 4345 & 55 & 1.3 & 0.001 & 11,142 & 421 & 3.8 \\
\hline
\end{tabular}


Table 3 Predictors of diarrheal illness among the population of Gaza strip

\begin{tabular}{|c|c|c|c|}
\hline Variable & Odds ratio & $95 \% \mathrm{Cl}$ & $P$-value \\
\hline Living in rural areas ${ }^{a}$ & 2.1 & $(1.4-3.2)$ & 0.001 \\
\hline $\begin{array}{l}\text { Low education level of } \\
\text { household head }^{\mathrm{b}}\end{array}$ & 2.7 & $(1.6-4.4)$ & 0.001 \\
\hline $\begin{array}{l}\text { Low monthly income } \\
\text { of household }\end{array}$ & 2.4 & $(1.7-3.5)$ & 0.001 \\
\hline Unclean kitchen $^{d}$ & 1.4 & $(1.1-1.8)$ & 0.045 \\
\hline Non-sanitary toilet ${ }^{\mathrm{e}}$ & 278.6 & (99.9-777.4) & 0.001 \\
\hline Latrine without flush ${ }^{f}$ & 2.5 & $(1.1-5.8)$ & 0.037 \\
\hline $\begin{array}{l}\text { Disposal of wastewater } \\
\text { in an open area around } \\
\text { the house }\end{array}$ & 10.3 & $(6.9-15.5)$ & 0.001 \\
\hline $\begin{array}{l}\text { Lack of soap for hands } \\
\text { washing }\end{array}$ & 3.7 & $(2.5-5.4)$ & 0.001 \\
\hline
\end{tabular}

The level of measurement for all variables in the table was nominal

The default references used for the variables in the table were:

aLiving in urban areas

'bHigh education level of household head

'High monthly income of household

${ }^{\mathrm{d}}$ Clean kitchen

eSanitary toilet

fLatrine with flush

${ }^{9}$ Disposal of wastewater in a closed sewerage system

${ }^{\mathrm{h}}$ Availability of soap for hands washing

population and housing report published by the Palestinian Central Bureau of Statistics was found with respect to the average number of the Gaza's household's members which was around 6 members [12].

Risk of diarrhea differs between gender and males showed more risky than females. Similar findings were reported Bangladesh and Sudan [11, 24, 25]. In contrast, Schlagenhauf and his colleagues assessed gender differences in travel-associated disease and found females are more likely to get diarrhea than males [26].

We explored predictors of diarrheal illness among the population of Gaza strip and were living in rural areas, having an unclean kitchen, having a non-sanitary toilet, having latrine without a flush, disposing wastewater in an open area surrounding the home, and washing hands without soap. This finding is consistent with previous studies from Ethiopia, Kenya, and Bangladesh [11, 27, 28]. Knowing the influence of sociodemographic variables on diarrheal illness is vital because it is not only related to the individual case but also societal characteristics, in general, that affect the risk of diarrhea. Previous studies concluded that houses in urban areas and adequate household income affect the ability of families to have access to improved water, sanitation, and hygiene facilities as well as to necessary healthcare that would reduce the risk of diarrhea [29-32].

The education level of mother is seemed to be a significant predictor. Poor educated mother presented a predictor for high risk of getting diarrhea for their children. This finding is persistent with previous relevant studies
$[33,34]$. The systematic review of Cairncross and her colleagues concluded the importance of hand washing and having a closed sewage system to prevent the incidence and reduce the burden of diarrhea [35].

We explored predictors for seeking healthcare from nonprofessional provider similar to previous reports. We found low monthly income and living in rural areas were barriers to accessing professional healthcare which is consistent with ex-studies from low-income countries [2, 6, 11, 36]. This is similar to findings obtained from Chowdhury et al. 2015 [11]. We also found that the low level of education of the head of household reduces the chance of family members receiving professional healthcare. Perhaps this is due to the lack of awareness of the importance of receiving professional healthcare in the event of diarrhea illness [11, 37]. Families are unable to afford costs of professional treatments and transportations to access services at primary health centers. Moreover, low educated families are in a hurry to see their children recovered fast, so they seek nonprofessional healthcare.

This study drew the trend of seeking healthcare behavior from professional and non-professional healthcare providers and vice versa in the last three diarrheal episodes. We found about $47.4 \%$ initially sought care from a nonprofessional healthcare provider. This result could be explained by either because the symptoms of diarrhea were not serious to require professional health care or due to denial of Gaza's households from accessing professional healthcare because of poverty and rural residency, consequently, people prefer to depend on traditional medicine and intake of medicinal herbs as self-treatment. Therefore, providing low-cost and attainable professional health care for diarrheal treatment could decrease the burden of illness [38-40]. In this study, a transition in seeking diarrhea treatment from professional healthcare to non-professional care and vice versa was observed. This could be clearly interpreted as either because of disparities in the severity of the symptoms of diarrhea each time or due to lack of satisfaction with recovery in the previous diarrheal episode, therefore, they returned to seek another healthcare provider different from its predecessor [41, 42].

This community-based cross-sectional study has many methodological strengths, including the relatively large sample size of 1857 households, the method of interviewed questionnaire for data collection is superior to a selfadministered questionnaire, using a cluster random sampling to guarantee representativeness of the sample from the five Gaza's governorates. Therefore, generalization could possibly be applied to all of Gaza's areas. Furthermore, the main strength of our study was it is being the first study, which identified the predictors for seeking nonprofessional care for diarrheal treatment. However, it also has some noteworthy limitations. First, many independent factors were not examined for instance: dietary habits, early 
Table 4 | Comparison of individual and household characteristics among people sought their medical care for diarrhea from professional and nonprofessional healthcare providers

\begin{tabular}{lll}
\hline Variables & $\begin{array}{l}\text { Professional health provider } \\
n=187(44.5 \%)\end{array}$ & $\begin{array}{l}\text { A non-professional health service provider } \\
N=233(55.5 \%)\end{array}$ \\
\hline $\begin{array}{l}\text { Housing area } \\
\text { Rural }\end{array}$ & $96(51.3)$ & $125(53.6)$ \\
Urban & $91(48.7)$ & $108(46.4)$
\end{tabular}

Marital status of

the household head

$$
\begin{aligned}
& \text { Married } \\
& \text { Single }
\end{aligned}
$$

$41(21.9)$

Education level of household head

$$
\begin{aligned}
& \text { Less educated } \\
& \text { High educated }
\end{aligned}
$$

Gender of household head

$$
\text { Male }
$$

Female

Career of household head

$$
\text { Craftsman }
$$$$
\text { Public servant }
$$

Monthly income of household

$$
\begin{aligned}
& \text { Low income } \\
& \text { High income }
\end{aligned}
$$

House ownership

$$
\text { Owned }
$$$$
\text { Rented }
$$

Clean kitchen

Yes

No

Sanitary toilet

Yes

No

Kind of toilet

$$
\begin{aligned}
& \text { Latrine with flush } \\
& \text { Latrine without flush }
\end{aligned}
$$

Gender of person who had diarrhea

$$
\begin{aligned}
& \text { Male } \\
& \text { Female }
\end{aligned}
$$

Source of drinking water

Non improved

Improved

Source of washing water

Non improved

Improved
17 (9.1)

$170(90.9)$

$157(84.0)$

$30(16.0)$

$79(42.2)$

$108(57.8)$

$45(24.1)$

$142(75.9)$

178 (95.2)

$9(4.8)$

$57(30.5)$

$130(69.5)$

9 (4.8)

178 (95.2)

$13(7.0)$

174 (93.0)

118 (63.8)

67 (36.2)

$60(32.1)$

$127(67.9)$

$178(95.2)$

$9(4.8)$
197 (84.5)

36 (15.5)

85 (36.5)

148 (63.5)

0.109

208 (89.3)

25 (10.7)

0.166

83 (35.6)

$150(64.4)$

$122(52.4)$

111 (47.6)

$220(94.4)$

$13(5.6)$

0.998

71 (30.5)

$162(69.5)$

$5(2.1)$

$228(97.9)$

$18(7.7)$

$215(92.3)$

137 (59.1)

95 (40.9)

87 (37.3)

$146(62.7)$ 
Table 4 | Comparison of individual and household characteristics among people sought their medical care for diarrhea from professional and nonprofessional healthcare providers (Continued)

\begin{tabular}{|c|c|c|c|}
\hline Variables & $\begin{array}{l}\text { Professional health provider } \\
n=187(44.5 \%)\end{array}$ & $\begin{array}{l}\text { A non-professional health service provider } \\
N=233(55.5 \%)\end{array}$ & $P$-value \\
\hline $\begin{array}{l}\text { Source of cooking } \\
\text { water }\end{array}$ & & & 0.315 \\
\hline Non improved & $100(53.5)$ & $136(58.4)$ & \\
\hline Improved & $87(46.5)$ & $97(41.6)$ & \\
\hline $\begin{array}{l}\text { Place of wastewater } \\
\text { disposal }\end{array}$ & & & 0.083 \\
\hline $\begin{array}{l}\text { Open area around } \\
\text { the house }\end{array}$ & $127(67.9)$ & $176(75.5)$ & \\
\hline Close sewerage system & $60(32.1)$ & $57(24.5)$ & \\
\hline $\begin{array}{l}\text { Availability of soap for } \\
\text { hands washing }\end{array}$ & & & 0.413 \\
\hline Yes & $80(42.8)$ & $109(46.8)$ & \\
\hline No & $107(57.2)$ & $124(53.2)$ & \\
\hline \multicolumn{4}{|l|}{ Continuous variables } \\
\hline $\begin{array}{l}\text { Age of household } \\
\text { head (years) }\end{array}$ & $42.4 \pm 14.4(22-67)$ & $40.9 \pm 13.7(22-67)$ & 0.281 \\
\hline Living in the area (years) & $15.2 \pm 10.5(1-44)$ & $15.7 \pm 10.5(1-44)$ & 0.586 \\
\hline Number of rooms in house & $2.7 \pm 0.8(1-5)$ & $2.7 \pm 0.9(1-5)$ & 0.524 \\
\hline Number of family Members & $6.3 \pm 1.7(3-11)$ & $6.2 \pm 1.7(2-12)$ & 0.577 \\
\hline Age of getting diarrhea & $8.7 \pm 13.5(1-62)$ & $21.1 \pm 16.7(1-67)$ & $<0.001$ \\
\hline Number of children less than 5 in family & $1.5 \pm 0.6(0-3)$ & $1.4 \pm 0.6(0-3)$ & 0.238 \\
\hline Distance to healthcare center (km) & $1.6 \pm 0.8(1-4)$ & $1.7 \pm 0.8(1-4)$ & 0.303 \\
\hline
\end{tabular}

For the continuous variables, the Mean \pm SD (min-max) were presented instead of frequency and percentage as in the binary variables

Chi-square test was used to examine the difference between the two groups

weaning, seasonal patterns, lack of safe water supply, younger maternal age, and indiscriminate disposal of child feces [43-46]. Second, recall bias and misreporting could happen when we asked about seeking healthcare behavior in the last three diarrheal episodes.

\section{Conclusions}

This study showed a high prevalence of diarrhea particularly among children less than 5 years old. Sociodemographic, economic, water, sanitation, and hygiene factors in the Gaza strip's households were the predictors of the diarrheal illness and seeking non-professional healthcare for diarrhea illness treatment. Consequently, in the light of study findings, we recommend improving the status of water, sanitation, and hygiene to reduce the incidence of diarrhea and provide a low-cost and attainable professional health care for diarrheal treatment. Future studies to

Table 5 | Healthcare utilization patterns of subjects reporting diarrhea in the Gaza strip

\begin{tabular}{llll}
\hline Healthcare provider & First time & Second time & Last time \\
\hline Professional & $221(52.6 \%)$ & $141(33.6 \%)$ & $187(44.5 \%)$ \\
Non-professional & $199(47.4 \%)$ & $279(66.4 \%)$ & $233(55.5 \%)$ \\
\hline
\end{tabular}

investigate the seasonal trend of diarrhea cases considering water, sanitation and hygiene (WASH) variables that were not included in this study are recommended.

Table 6 | Predictors of seeking care from non-professional healthcare providers among the population of Gaza strip

\begin{tabular}{|c|c|c|c|}
\hline Variable & $\begin{array}{l}\text { Odds } \\
\text { ratio }\end{array}$ & $95 \% \mathrm{Cl}$ & $\begin{array}{l}P \text { - } \\
\text { value }\end{array}$ \\
\hline A female head of the household ${ }^{a}$ & 2.1 & $(1.1-4)$ & 0.018 \\
\hline Low education level of household head ${ }^{b}$ & 4.9 & $(2.2-8)$ & 0.001 \\
\hline Low monthly income of household ${ }^{c}$ & 4.1 & $\begin{array}{l}(2.7- \\
7.5)\end{array}$ & 0.001 \\
\hline $\begin{array}{l}\text { Age of person who got diarrhea more than } 5 \\
\text { years }\end{array}$ & 2.2 & $\begin{array}{l}(1.1- \\
4.4)\end{array}$ & 0.001 \\
\hline Living in rural areas ${ }^{\mathrm{e}}$ & 9.1 & $\begin{array}{l}(1.9- \\
44.3)\end{array}$ & 0.006 \\
\hline $\begin{array}{l}\text { Disposal of wastewater in an open area } \\
\text { around the house }\end{array}$ & 1.8 & $\begin{array}{l}(1.1- \\
3.1)\end{array}$ & 0.032 \\
\hline
\end{tabular}

The level of measurement for all variables in the table was nominal The default references used for the variables in the table were:

${ }^{a} A$ male head of the household a

${ }^{b}$ High education level of household head

'High monthly income of household

${ }^{d}$ Age of person who got diarrhea less than 5 years

eLiving in urban areas

fDisposal of wastewater in a close sewerage system 


\section{Abbreviations}

Cl: Confidence interval; INS: Israeli new shekel; NGOs: Nongovernmental organizations; OR: Odds ratio; PHCCs: Primary healthcare centers; SPSS: Statistical Package for Social Science; UNRWA: United Nations relief and works agency for Palestine refugees in the Near East; WASH: Water, sanitation, and hygiene; WHO: World health organization

\section{Acknowledgments}

Tehran University of Medical Sciences, the International campus is appreciated for giving us the opportunity to implement this study. The Helsinki Ethical Committee in the Gaza Strip and the General Directorate of Human Resources Development in the Palestinian Ministry of Health are also thanked for giving us permission to conduct the study in the Gaza strip. The authors would like to thank the participants in this study for their important contributions.

\section{Authors' contributions}

$\mathrm{SA}, \mathrm{MH}$, and $\mathrm{AM}$ participated in the design of the study, and data collection. $\mathrm{RN}$ and $\mathrm{AH}$ performed the statistical analysis and drafted the manuscript. SN and MY supervising the study and participated in the draft review. All authors have read and approved the final version of the manuscript and agree with the order of presentation of the authors.

\section{Funding}

This research did not receive any specific grant from funding agencies in the public, commercial or not-for-profit sectors.

\section{Availability of data and materials}

The datasets generated and/or analyzed during the current study are not publicly available but are available from the corresponding author on reasonable request.

\section{Ethics approval and consent to participate}

The study protocol was approved by the Ethics Committee of Tehran University of Medical Sciences (Code: IR. TUMS.REC.1396.3917) and by the Helsinki Ethical Committee in the Gaza Strip (Code: PHRC/HC/288/17). Also, permission was obtained from the General Directorate of Human Resources Development at the Palestinian Ministry of Health to conduct the study. The household's heads who agreed to participate in the study were asked to sign a written informed consent attached to the questionnaire.

\section{Consent for publication}

Not applicable.

\section{Competing interests}

The authors declare that they have no competing interests.

\section{Author details}

${ }^{1}$ Department of Environmental Health Engineering, School of Public Health International Campus, Tehran University of Medical Sciences, Tehran, Iran. ${ }^{2}$ Department of Environmental Health Engineering, School of Public Health, Tehran University of Medical Sciences, Tehran, Iran. ${ }^{3}$ Center for Water Quality Research (CWQR), Institute for Environmental Research (IER), Tehran University of Medical Sciences, Tehran, Iran. ${ }^{4}$ Department of Research Methodology and Data Analysis, Institute for Environmental Research, Tehran University of Medical Sciences, Tehran, Iran. ${ }^{5}$ Department of Research, Directorate General of Human Resources Development, Ministry of Health, Gaza Strip, Palestine.

\section{Received: 26 December 2018 Accepted: 29 May 2019}

Published online: 07 June 2019

\section{References}

1. UNICEF, WHO. Ending preventable child deaths from pneumonia and Diarrhoea by 2025: the integrated global action plan for pneumonia and Diarrhoea (GAPPD). p. 2013. https://apps.who.int/iris/bitstream/handle/ 10665/79207/WHO_FWC_MCA_13_01_eng.pdf;jsessionid= F476FD168FDE942BBBBEDF810727ECB0? sequence=1. Accessed 19 Jan, 2015

2. Nasrin D, Blackwelder WC, Farag TH, Saha D, Sow SO, et al. Health care seeking for childhood diarrhea in developing countries: evidence from seven sites in Africa and Asia. Am J Trop Med Hyg. 2013;89(1_Suppl):3-12 https://doi: 10.4269/ajtmh.12-0749.

3. $\mathrm{MOH}$. Health status in Palestine. Annual report 2016. Gaza: Ministry of Health; 2017. http://www.moh.gov.ps

4. UNRWA. Epidemiological bulletin for the Gaza strip. United Nations relief and works Agency for Palestine Refugees in the near east. 2013;5(8). http:// www.moh.gov.ps/portal/wp-content/uploads/N3N1.pdf.

5. Berman $P$, Dave $P$. Experiences in paying for health care in India's voluntary sector. Int J Health Plann Manag. 1996;11(1):33-51 https://doi.org/10.1002/ (SICI)1099-1751(199601)11:1<33::AID-HPM418>3.0.CO;2-Y

6. Geldsetzer P, Williams TC, Kirolos A, Mitchell S, Ratcliffe LA, Kohli-Lynch MK, et al. The recognition of and care seeking behaviour for childhood illness in developing countries: a systematic review. PLoS One. 2014;9(4):e93427 https://doi.org/10.1371/journal.pone.0093427.

7. Wilson SE, Ouédraogo CT, Prince L, Ouédraogo A, Hess SY, Rouamba N, et al. Caregiver recognition of childhood diarrhea, care seeking behaviors and home treatment practices in rural Burkina Faso: a cross-sectional survey. PLoS One. 2012;7(3):e33273 https://doi.org/10.1371/journal.pone.0033273.

8. Ensor T, Cooper S. Overcoming barriers to health service access: influencing the demand side. Health Policy Plan. 2004;19(2):69-79 https://doi.org/10.1093/heapol/czh009.

9. Forsberg BC, Petzold MG, Tomson G, Allebeck P. Diarrhoea case management in low-and middle-income countries: an unfinished agenda. Bull World Health Organ. 2007;85:42-8.

10. $\mathrm{WHO}, \mathrm{UNICEF}$. Implementing the new recommendations on the clinical management of diarrhoea: guidelines for policy makers and programme managers. 2006. https://apps.who.int/iris/bitstream/ handle/10665/43456/9241594217_eng.pdf.

11. Chowdhury F, Khan IA, Patel S, Siddiq AU, Saha NC, Khan Al, et al. Diarrheal illness and healthcare seeking behavior among a population at high risk for diarrhea in Dhaka, Bangladesh. PLoS One. 2015;10(6):e0130105 https://doi. org/10.1371/journal.pone.0130105.

12. Manenti C, Reinicke C, MacDonald J, Donald J. Report of a field assessment of health conditions in the occupied Palestinian territory: World Health Organization Reports; 2016. http://apps.who.int/gb/statements/report_ palestinian territory/report_palestinian territory-en.pdf

13. WHO. Country cooperation strategy for $\mathbf{W H O}$ and the occupied Palestinian territory: 2017-2020: World Health Organization. Regional Office for the Eastern Mediterranean; 2017. https://reliefweb.int/report/occupied-palestinian-territory/ country-cooperation-strategy-who-and-occupied-palestinian

14. PCBS. Final results - buildings report - population, housing and establishment census 2017: Palestinian Central Bureau of Statistics; 2018. http://www.pcbs.gov.ps/pcbs_2012/Publications.aspx

15. Charan J, Biswas T. How to calculate sample size for different study designs in medical research? Indian J Psychol Med. 2013;35(2):121. https://doi.org/ 10.4103/0253-7176.116232

16. Amin ME. Social science research: conception, methodology and analysis: Makerere University; 2005. https://www.worldcat.org/title/social-scienceresearch-conception-methodology-and-analysis/oclc/157025594.

17. WHO. The treatment of diarrhea. A manual for physicians and other senior health workers. Department of Child and Adolescent Health and development. Geneva: World Health Organization; 2005. https://www.who. int/maternal_child_adolescent/documents/9241593180/en/

18. Abuzerr S, Nasseri S, Yunesian M, Yassin S, Hadi M, Mahvi AH, et al. Microbiological quality of drinking water and prevalence of waterborne diseases in the Gaza strip, Palestine: a narrative review. J Geosci Environ Prot. 2019;7(4):122-38. https://doi.org/10.4236/gep.2019.74008.

19. Abuzerr S, Nasseri S, Yunesian M, Yassin S, Hadi M, Mahvi AH, et al. Household drinking water safety among the population of Gaza strip, Palestine: knowledge, attitudes, practices, and satisfaction. J Water Sanit Hyg Dev. 2019; https://doi.org/10.2166/washdev.2019.134

20. Kanoa B, El-kariri B, Al-Sakka M, Al-Hindi M, Younis S. Epidemiology of acute diarrheal diseases among children under five in Gaza strip: post war community based study. J Appl Med Sci. 2017;5(2B):442-52 https://doi: 10 21276/sjams.2017.5.2.29.

21. Bryce J, Boschi-Pinto C, Shibuya K, Black RE, Group WCHER. WHO estimates of the causes of death in children. Lancet. 2005;365(9465):1147-52 https:// doi.org/10.1016/S0140-6736(05)71877-8.

22. Bandyopadhyay S, Kanji S, Wang $L$. The impact of rainfall and temperature variation on diarrheal prevalence in sub-Saharan Africa. Appl Geogr. 2012;33: 63-72 https://doi.org/10.1016/j.apgeog.2011.07.017. 
23. Philipsborn R, Ahmed SM, Brosi BJ, Levy K. Climatic drivers of Diarrheagenic Escherichia coli incidence: a systematic review and meta-analysis. J Infect Dis. 2016;214(1):6-15 https://doi.org/10.1093/infdis/jiw081.

24. Mitra AK, Rahman MM, Fuchs GJ. Risk factors and gender differentials for death among children hospitalized with diarrhoea in Bangladesh.J Health Popul Nutr. 2000;18(3):151-6.

25. Siziya S, Muula AS, Rudatsikira E. Correlates of diarrhoea among children below the age of 5 years in Sudan. Afr Health Sci. 2013;13(2):376-83. https:// doi.org/10.4314/ahs.v13i2.26.

26. Schlagenhauf $P$, Chen LH, Wilson ME, Freedman DO, Tcheng D, Schwartz E, et al. Sex and gender differences in travel-associated disease. Clin Infect Dis. 2010;50(6):826-32 https://doi.org/10.1086/650575.

27. Mengistie B, Berhane $Y$, Worku A. Prevalence of diarrhea and associated risk factors among children under-five years of age in eastern Ethiopia: a crosssectional study. Open J Prev Med. 2013;3(07):446. https://doi.org/10.4236/ ojpm.2013.37060.

28. O'Reilly CE, Jaron P, Ochieng B, Nyaguara A, Tate JE, Parsons MB, et al. Risk factors for death among children less than 5 years old hospitalized with diarrhea in rural western Kenya, 2005-2007: a cohort study. PLoS Med. 2012; 9(7):e1001256 https://doi.org/10.1371/journal.pmed.1001256.

29. Veenstra G. Social capital, SES and health: an individual-level analysis. Soc Sci Med. 2000;50(5):619-29 https://doi.org/10.1016/S0277-9536(99)00307-X.

30. Wierzba TF, El-Yazeed RA, Savarino SJ, Mourad AS, Rao M, Baddour M, et al. The interrelationship of malnutrition and diarrhea in a periurban area outside Alexandria, Egypt. J Pediatr Gastroenterol Nutr. 2001;32(2):189-96.

31. Ali M, Do CG, Clemens JD, Park J-K, von Seidlein L, Truong MT, et al. The use of a computerized database to monitor vaccine safety in Viet Nam. Bull World Health Organ. 2005;83(8):604-10.

32. Woldu W, Bitew BD, Gizaw Z. Socioeconomic factors associated with diarrheal diseases among under-five children of the nomadic population in Northeast Ethiopia. Trop Med Health. 2016;44(1):40 https://doi.org/10.1186/ s41182-016-0040-7.

33. Mihrete TS, Alemie GA, Teferra AS. Determinants of childhood diarrhea among under five children in BenishangulGumuz regional state, north West Ethiopia. BMC Pediatr. 2014;1(14):102 https:/doi.org/10.1186/1471-2431-14-102.

34. Seid KW, Kelkay BD. The prevalence of diarrhea and associated factors among children under five years in Ethiopia. Int J Appl Res. 2018;4(9):236-41.

35. Cairncross S, Hunt C, Boisson S, Bostoen K, Curtis V, Fung IC, et al. Water sanitation and hygiene for the prevention of diarrhoea. Int J Epidemiol. 2010;39(suppl_1):i193-205 https://doi.org/10.1093/ije/dyq035.

36. Ferdous F, Das SK, Ahmed S, Farzana FD, Kaur G, Chisti MJ, et al. The impact of socio-economic conditions and clinical characteristics on improving childhood care seeking behaviors for families living far from the health facility. Sci J Public Health. 2013;1(2):69-76 https://doi: 10.11648/j.sjph.20130102.14.

37. Banerjee A, Bhawalkar J, Jadhav S, Rathod H, Khedkar D. Access to health services among slum dwellers in an industrial township and surrounding rural areas: a rapid epidemiological assessment. J Fam Med Prim Care. 2012; 1(1):20. https://doi.org/10.4103/2249-4863.94444.

38. Mihrete TS, Alemie GA, Teferra AS. Determinants of childhood diarrhea among underfive children in Benishangul Gumuz regional state, north West Ethiopia. BMC Pediatr. 2014;14(1):102 https:/doi.org/10.1186/1471-2431-14-102.

39. Gwatkin D. Overcoming the inverse care law: designing health programs to serve disadvantaged population groups in developing countries. Ms, World Bank. 2001. http://siteresources.worldbank.org/INTPAH/Resources/ Publications/Recent\%20Papers/8972_Bellagio_Intro._Paper_gwakin.pdf.

40. Gwatkin DR, Rutstein S, Johnson K, Suliman E, Wagstaff A, Amouzou A. Socio-economic differences in health, nutrition, and population. Washington: World Bank; 2007. p. 287. https://siteresources.worldbank.org/ INTPAH/Resources/IndicatorsOverview.pdf

41. Das SK, Nasrin D, Ahmed S, Wu Y, Ferdous F, Farzana FD, et al. Health careseeking behavior for childhood diarrhea in Mirzapur, rural Bangladesh. Am J Trop Med Hyg. 2013;89(1_Suppl):62-8 https://doi.org/10.4269/ajtmh.13-0107.

42. Lamberti LM, Walker CLF, Black RE. Systematic review of diarrhea duration and severity in children and adults in low-and middle-income countries. BMC Public Health. 2012;12(1):276 https://doi.org/10.1186/1471-2458-12-276.

43. Kosek M, Yori PP, Pan WK, Olortegui MP, Gilman RH, Perez J, et al. Epidemiology of highly endemic multiply antibiotic-resistant shigellosis in children in the Peruvian Amazon. Pediatrics. 2008;122(3):e541. https://doi. org/10.1542/peds.2008-0458.

44. Maponga BA, Chirundu D, Gombe NT, Tshimanga M, Shambira G, Takundwa L. Risk factors for contracting watery diarrhoea in Kadoma
City, Zimbabwe, 2011: a case control study. BMC Infect Dis. 2013; 13(1):567 https://doi.org/10.1186/1471-2334-13-567.

45. Lee G, Pan W, Yori PP, Olortegui MP, Tilley D, Gregory M, et al. Symptomatic and asymptomatic campylobacter infections associated with reduced growth in Peruvian children. PLoS Negl Trop Dis. 2013;7(1):e2036 https://doi. org/10.1371/journal.pntd.0002036.

46. Kamath A, Shetty K, Unnikrishnan B, Kaushik S, Rai SN. Prevalence, patterns, and predictors of diarrhea: a spatial-temporal comprehensive evaluation in India. BMC Public Health. 2018;18(1):1288 https://doi.org/10.1186/s12889-018-6213-z.

\section{Publisher's Note}

Springer Nature remains neutral with regard to jurisdictional claims in published maps and institutional affiliations.
Ready to submit your research? Choose BMC and benefit from:

- fast, convenient online submission

- thorough peer review by experienced researchers in your field

- rapid publication on acceptance

- support for research data, including large and complex data types

- gold Open Access which fosters wider collaboration and increased citations

- maximum visibility for your research: over $100 \mathrm{M}$ website views per year

At BMC, research is always in progress.

Learn more biomedcentral.com/submissions 